\title{
EGY HÁTRÁNYOS HELYZETŰ TELEPÜLÉS EGYEDI LEHETŐSÉGEI ÉS TÖREKVÉSEI A HELYI GAZDASÁGFEJLESZTÉS TEKINTETÉBEN
}

\author{
Eskulics György - Gelencsér Zsófia - Horváth Szilveszter - \\ Siklósi Rozália - Szuromi Orsolya
}

\begin{abstract}
SUMMARY
This study is about Rimóc, a Hungarian village with 1800 residents, where the local economic development (LED) is a main ambition, because in the concept of demographic and employment relations Rimóc is considered an underprivileged settlement. The research was carried out by a 5 manned team, where using the method of deep interviews, short interviews and a focus group interview, made with the help of locals, revealed some difficulties. These are the lack of cooperation between the locals, ethnic problems, lack of assets and motivation, which are preventing the process of the LED. Overcoming these problems can become the key of the future and sustainable development of the settlements. Since Hungary has many villages which also try to reach the state of self-sufficiency, in the case of Rimóc the tendency is similar, where the municipality, mainly the mayor, of the village initiated the begining of such processes in food supply and power supply.
\end{abstract}

\section{BEVEZETÉS}

Tanulmányunkban egy olyan kistelepülést mutatunk be, mely a Nógrád megyei palócság egyik leghíresebb népmüvészeti központja. Kutatásunk az ELTE TTK Társadalom- és Gazdaságföldrajzi Tanszék projektjeként, a Közösen a Jövő Munkahelyeiért Alapítvány és az Aktív Társadalom Alapítvány támogatása révén valósult meg, melynek keretén belül, a helyi gazdaságfejlesztéshez kapcsolódóan lokális foglalkoztatási mintákat vizsgálunk. Kutatásunk módszere alapvetően társadalomtudományi megközelítésủ volt, 7 mélyinterjút, valamint közel 30 rövid, strukturált interjút készítettünk, melyek során igyekeztünk a lakosság egyes rétegeit minél szélesebb körben lefedni. A megkérdezettek között szerepeltek: polgármester, az önkormányzat munkatársai, közmunkaprogramban részt vevők, civil szervezetek képviselöi, helyi közintézmények munkatársai, roma kisebbséghez tartozók, helyi vállalkozók, valamint a hagyományőrzés aktív helyi képviselői. Ezen kívül egy fókuszcsoportos interjút is végeztünk a helyi fiatalok körében, mely újabb tanulságokkal szolgált számunkra.

Előzetes ismereteink szerint Rimócon az utóbbi két évtizedben a település önkormányzata révén több elöremutató kezdeményezés is indult a helyi gazdaságfejlesztés terén. Ezen kezdeményezések alapja föként az önellátásra való törekvés, mind az élelmiszer-ellátás, mind pedig az energiaellátás tekintetében (megújuló energiaforrások). Mindezekből kiindulva kutatásunk során föként arra kerestük a választ, hogy egy gazdag kulturális hagyományokkal rendelkező, ugyanakkor alapvetően hátrányos helyzetben lévő település, milyen eredményeket képes elérni az önellátás terén, valamint milyen tényezőknek köszönheti sikereit, illetve hiányosságait.

Egy hátrányos helyzetü kistelepülés életében kulcsfontosságú szerepe lehet az alábbi tényezőknek: a település népességmegtartó képességének javítása, a helyi 
erőforrásokra jobban támaszkodó gazdasági tevékenységek fejlesztése, valamint a helyi közösségek együttmüködésének elömozdítása (Lányi 2012). A helyi gazdaságfejlesztés, valamint a kistelepülések esetében föként a mezőgazdasági lehetőségek jobb kiaknázása kiválóan szolgálja e célok elérését. A helyi gazdaságfejlesztés elméleti megközelítései kapcsán számos hazai és külföldi publikációt találunk, ám, hogy mit értünk e fogalom alatt, azt a következő definíció nagyon tömören, de világosan összefoglalja: ,tudatos helyi közösségi beavatkozás a gazdasági folyamatokba a fenntartható helyi fejlődés érdekében" (VÁTI 2010). A helyi gazdaságfejlesztés legfontosabb eszközei közé sorolhatjuk a helyi termékekhez kapcsolódó szolgáltatások fejlesztését (pl.: helyi termék bolt, illetve termelöi piac létrehozása, közös védjegy kialakítása), illetve az önrendelkezés erősítését mind az energiaellátás (pl.: megújuló energiaforrások bevonása), mind pedig az élelmiszerellátás (pl.: szociális szövetkezetek létrehozása) tekintetében. Emellett kitüntetett szerepe van a helyi kisvállalkozások, valamint az ökoturisztikai lehetőségek fejlesztésének, továbbá kulcsfontosságú a helyi közösségek identitásának erősítése is (Németh 2012). Az eszközök sokszínüségéből is kitünik, hogy maga a helyi gazdaságfejlesztés nem csupán egy rendszer gazdaságának fejlesztéséről szól, hanem ennek számos környezeti, társadalmi és területi hatása és célja is kell, hogy legyen.

A helyi gazdaságfejlesztés egyik legnépszerübb útja napjainkban a közfoglalkoztatás keretében valósul meg. Hazánkban számos kistelepülésen indult meg ennek keretében az önkormányzati földek müvelése, valamint a termények felhasználása a közétkeztetésben. Ez a tendencia 2011 után erösödött fel, amikor a mezögazdasági termelés a közmunkaprogram részévé vált. Fontos azonban kiemelni, hogy Rimócon ez a folyamat már korábban, 2005-ben elindult. A Rimóchoz hasonló jó gyakorlatokat végignézve ${ }^{15}$ még egy kulcstényezőt találunk, mégpedig, hogy a kistelepülések kezdeményezései, az esetek többségében egy elkötelezett polgármesternek köszönhetőek. Ezek a kezdeményezések általában a hátrányos helyzetủ településeken indulnak el, ahol erre sokszor az anyagi szükségszerüség kényszeríti a falvak vezetöit (Kajner 2013).

\section{A TELEPÜLÉS RÖVID BEMUTATÁSA}

Rimóc község Nógrád megyében, a Cserhát északi nyúlványai alatt, az Ipolytól délre fekszik, Szécsény városától $5 \mathrm{~km}$ távolságban. Észak felől szántóföldek határolják, míg délröl a Cserhát magaslatai veszik körbe a falut, melyet a Körtvélyes-patak szel ketté. Történelmi emlékek alapján a község már a XI. században templomos hely volt. Jelenlegi lakosainak száma 1827 fö. A legfőbb demográfiai folyamatokat tekintve - mint a falvak többségénél - így Rimóc esetében is népességfogyásról beszélhetünk. A lakosságon belül a roma kisebbség aránya évröl-évre egyre nagyobb arányt tesz ki, a 18 év alatti lakosság körében a roma fiatalok aránya már elérte az $50 \%$-ot.

\footnotetext{
${ }^{15}$ Lásd pl.: Rozsály, Túristvándi, Tunyogmatolcs, Hernádszentandrás esettanulmányai nyomán.
} 
A településen a rendszerváltás óta teljesen kiépült a közmühálózat (villany, víz, gáz, szennyvíz, informatikai hálózat), bár hozzá kell tenni, hogy a föként roma kisebbség által sürübben lakott területeken nem minden háztartás tudott még csatlakozni, pl. a vezetékes víz-, illetve szennyvízhálózatra, valamint az úthálózat kapcsán is sok utca még felújításra szorul. A településen több élelmiszerüzlet is müködik, emellett van önálló postahivatal, valamint egyéb lakossági szolgáltatások is elérhetők, úgy, mint fodrászat, kozmetika, takarékszövetkezet, eMagyarország pont, virágüzlet, gyógyszertár. Az oktatási intézményeket tekintve a településnek van óvodája, könyvtára, valamint általános iskolája. A település közúti elérhetősége viszonylag kedvező, ugyanakkor a tömegközlekedési lehetőségek szükültek az utóbbi években.

Ahogy korábban utaltunk rá, Rimóc a palóc népmüvészet egyik központja, ahol nem csak az ünnepnapokon, hanem a település mindennapjaiban is elötérben találjuk a különleges rimóci hagyományok életben tartását, legyen szó zenéről, viseletről, szokásokról.

$\mathrm{Az}$ elmúlt években a közigazgatásban történt átalakulások természetesen Rimócot is érintették, jelenleg Nógrádmegyerrel közös önkormányzati hivatalt tartanak fent. Korábban társulási formában közösen tartották fent az óvodát, innen adódott az együttmüködés, mely eddig sikeresnek mondható. A járási rendszer kialakítása a többi kistelepüléshez hasonlóan érintette a települést, az eddigi feladatok jó részét továbbra is ellátják (gyermekgondozás, szociális ügyek stb.), míg néhány kisebb feladat került járási kezelésbe. Az önkormányzat anyagi helyzete szerény, ugyanakkor stabilnak mondható. Az interjúk során megtudtuk, hogy nincs tartozása az önkormányzatnak, mindemellett fontos megemlíteni, hogy 1990 óta egyetlen ingatlant sem adott el.

A társadalmi, gazdasági viszonyok tekintetében a település több tekintetben is hátrányos helyzetünek mondható. ${ }^{16} \mathrm{~A}$ településszerkezetet vizsgálva a falu magasabban fekvő területén jól elkülöníthető egy körülbelül 400 fös roma szegregátum. Ezen a néhány utca által határolt területen tevékenykedik a Magyar Szegénységellenes Alapítvány több munkatársa, akik szeretnék elösegíteni a roma gyerekek társadalomba való beilleszkedését, illetve munkaerő-piaci kilátásaik javulását. A célok elérése sajnos sokszor megoldhatatlannak tủnik, amit nem csak az alapítvány munkatársai, de a helyi fiatalokkal történt interjúk is megerősítettek.

A foglalkoztatási viszonyok tekintetében Rimócon a KSH adatai alapján az aktív keresők száma 1014 fö, ebből 215 fơ ${ }^{17}$ van nyilvántartva, mint álláskereső, de az önkormányzat munkatársai szerint a tényleges munkanélküliek száma ennek a többszörösére tehetö. Az álláskeresők többsége szakképzettséggel nem rendelkezik, leginkább a közmunkaprogram révén tudnak elhelyezkedni Szécsényben vagy Rimócon. ${ }^{18}$ A településen jelenleg az önkormányzat biztosítja a

\footnotetext{
${ }^{16}$ A falu önkormányzata az utóbbi években többször részesült ún. ÖNHIKI támogatásban.

${ }^{17}$ Forrás: KSH T-Star 2011.

${ }^{18}$ Elszomorító adat, hogy a 18-30 év közötti regisztrált munkanélküliek száma 108 fö, mely több mint 34\%-os munkanélküliséget jelent ebben a korosztályban, és köztük sokan vannak, akik a 8 osztályt sem végezték el.
} 
legtöbb munkalehetőséget, az alkalmazotti létszám 70 fö körül változik évröl-évre. $\mathrm{Az}$ önkormányzaton kívül a munkalehetőségek többsége a szolgáltató szektorhoz köthető, és jellemzően csak pár föt foglalkoztat. A faluban van néhány mezőgazdasági vállalkozó, illetve magánvállalkozó (pl.: építési vállalkozó), ezen kívül egyéb szolgáltató egységek (posta, takarékszövetkezet, élelmiszerboltok, gyógyszertár). Ezen vállalkozások sok esetben csak idényjelleggel alkalmaznak embereket, de az építési vállalkozó olykor akár 20-30 föt is foglalkoztat. A településen ipari létesítmény nincs. A térségben szükösek a munkaerőpiaci lehetőségek ${ }^{19}$, az országos tendenciáknak megfelelöen ${ }^{20}$ az aktív korú népesség többsége naponta vagy hetente ingázik a munkahely és lakóhely között. A napi ingázók általában a közeli nagyvárosokban - Szécsényben, Balassagyarmaton vagy Salgótarjánban - tudnak munkát vállalni, de sok családnál jellemző a külföldi munkavállalás is. A rimóci értelmiségiek többsége főként Szécsényben, Balassagyarmaton, illetve Budapesten vállal munkát különféle közintézményekben (pl.: kormányhivatal, iskola, óvoda, egyház, idősek otthona), ezen kívül Szécsényben van még ipari jellegủ munkalehetőség is: elektronikai összeszerelö üzem, illetve gyertyagyár. A külföldre ingázók pedig főként az építőiparban tudnak elhelyezkedni, leginkább Németországban, Hollandiában, Ausztriában vagy akár Nagy-Britanniában.

\section{EREDMÉNYEK ÉS ÉRTÉKELÉSÜK}

A tapasztalatok ország-világ szerte azt mutatják, hogy a helyi gazdaságfejlesztés és az önellátás felé vezető út meglehetősen rögös. Rimócon sincs ez másképp, ugyanakkor számos olyan kezdeményezést ismertünk meg, melyek jelzik, hogy egy hátrányos helyzetü nógrádi kistelepülésnek is joggal van helye a jó példák gyüjteményében. A kutatási kérdésünkre választ keresve, miszerint minek köszönheti a település sikereit, illetve milyen téren ütközik akadályokba, összefoglalóan a következöket állapíthatjuk meg.

\subsection{ELHIVATOTT HELYI VEZETÉS}

A helyi gazdaságfejlesztés szempontjából a településen eddig elért eredmények jórészt az önkormányzatnak köszönhetőek. A település vezetése alapvetően átgondoltan és következetesen végzi munkáját. Pozitívumként utalnánk arra, hogy sem ingatlant, sem földterületet nem adtak el a rendszerváltás óta, hanem ezeket próbálják a lehető legjobb tudásuk szerint hasznosítani. A faluvezetés stabilitását

\footnotetext{
19 A KSH elmúlt másfél év negyedéves idősoros munkanélküliségi ráta adatai alapján Nógrád megye a 3. legnagyobb értékkel rendelkező megye Borsod-Abaúj-Zemplén és Szabolcs-SzatmárBereg megye után (az országos átlag mindig több mint másfélszerese).

${ }^{20}$ Mivel minden kistelepülésre, foglalkoztatási és korcsoportra jellemző az ingázás, így ez a tényező ma már nem jelent kirívó jellegzetességet sehol. Beluszky és Sikos kutatásai arról tanúskodnak, hogy az ingázók aránya a keresők között 60-70\% között van a hazai falvakban (Beluszky-Sikos 2007).
} 
jelzi, hogy a jelenlegi polgármester 1990 óta áll a település élén, valamint azóta a képviselőtestület összetétele sem sokat változott.

A helyi vezetés egyik meghatározó kezdeményezése a szociális bolt beindítása volt. Ez az intézmény 1993 óta müködik a faluban a „Rimóc Községért” Alapítvány fenntartásában, és összesen 7 föt foglalkoztat. Eleinte a boltban csak alapvető élelmiszereket árultak, majd az igények és a vásárlók számának folyamatos növekedése miatt tovább bővítették a bolt nagyságát, valamint az árukínálatot is. Jelenleg is bővítés alatt állnak, melynek részben az is az oka, hogy tervezik a jövőben, hogy a boltban alakítsanak ki egy „helyi termék sarkot”. A boltban már eddig is árultak helyi termékeket, többek között helyi kézmúves terméket (házi áldás, különböző kerámiatárgyak), de arra is volt már példa, hogy ha a közmunkaprogram során termelt élelmiszerekből maradt felesleg, amit a településen a szociális étkeztetést ellátó konyha nem használt fel, az önkormányzaton keresztül értékesíteni tudták a boltban. Emellett az is felmerült, hogy a boltban esetleg a helyi őstermelök is árusíthassák portékájukat. Fontos viszont megjegyezni, hogy a bolt létrehozásával eleinte nem az volt a céljuk, hogy saját termékeiket értékesíthessék a település lakói, hanem hogy a falusi emberek valóban a lehető legalacsonyabb áron jussanak hozzá az alapélelmiszerekhez. Így mivel a kereskedelmi árakhoz képest kedvezőbb áron kínálják termékeiket, versenyképesek tudtak maradni, és a rimóciak többsége ma is ide jár vásárolni.

A falu vezetése azt is fontosnak tartja, hogy a megújuló erőforrásokat minél szélesebb körben hasznosítsák. A Gondozási Központ épületén - ahol a szociális étkeztetést ellátó konyha is müködik - 2013 tavaszára napkollektoros rendszer került kiépítésre (10 tábla, 10001 melegvíz/nap). Emellett 2013 nyarán üzembe helyeztek két biomassza kazánt, melyből a sportcsarnok, valamint az iskola fütését fogják 100\%-ban kiváltani, illetve a meleg víz előállításához szükséges hőenergia 70\%-át is fedezni tudják. A kazánhoz kapcsolódóan egy aprítékoló gépre, valamint tároló létesítményre is sikerrel pályáztak. Az aprítékoló gép esetében viszont, a beruházás jelentös anyagi vonzata miatt három önkormányzat közösen pályázott (Rimóc mellett Nógrádmegyer, valamint Nagylóc). Ezen kívül az önkormányzat törekszik a közintézmények teljes körủ szigetelésére is. Jelenleg az orvosi rendelő szigetelésére pályáztak sikerrel, mely projekt várhatóan 2014 októberére valósul meg.

\section{2. ÁTGONDOLT PÁLYÁZATI TEVÉKENYSÉG}

A pályázati lehetőségeket a falu nagyon jól használja ki, több pályázatíró végzettséggel rendelkező alkalmazottja is van a hivatalnak. Ehhez hozzátartozik, hogy sok más faluval ellentétben, itt általában nem a pályázati kiírásokhoz dolgoznak ki projektanyagokat, hanem fordítva, vagyis nem a célok nélküli „pénzszerzés” jellemzi pályázati tevékenységüket. Számos projektötletük van 
készen, kidolgozva, melyek csak arra várnak, hogy megfelelő kiírást találjanak hozzá, és minél előbb beadásra kerüljenek. ${ }^{21}$

\subsection{KOORDINÁLT, HELYI VISZONYOKHOZ ILLESZTETT KÖZMUNKAPROGRAM}

A közmunkaprogram alapvetően sikeresen müködik, annak ellenére, hogy a megélhetés javítását egyelöre kevésbé szolgálja, a település önellátásában, viszont hatalmas szerepe van. Ennek kapcsán az egyik legelőremutatóbb helyi kezdeményezés a mezőgazdasági termelés. 2005 óta évről évre egyre több földterületet bevonva, az önkormányzat a szociális étkeztetés számára törekszik megtermelni a szükséges zöldség, gyümölcs, illetve búza mennyiséget. Jelenleg 14 fő bevonásával 7 hektáros területen gazdálkodnak. Ezzel párhuzamosan a megtermelt növények skálája is folyamatosan bővült, illetve ehhez kapcsolódóan a tárolási kapacitások (hütőkapacitások) is növekedtek. Jelenleg közel 25 féle növényt termesztenek, melyek közül a zöldségek többségéből a konyha tulajdonképpen egész évben teljesen önellátó (még télen is, hiszen a hütés és tartósítás révén ez nem jelent problémát). Ehhez hozzátartozik, hogy sok alapanyagot feldolgozva, félkész termékként juttatnak tovább a konyha számára (pl.: paradicsomlé, lecsó, káposztasaláta). A tartósítást pedig kétféle módon oldják meg: egyrészt savanyítanak (hordós káposzta, ecetes és kovászos uborka, csalamádé, cékla), a többi nyersanyagot pedig lefagyasztják. Érdekesség még, hogy a búzát a szécsényi malomban öröltetik, és a beszolgáltatott mennyiség fejében kapnak vissza lisztet. A szociális étkeztetést jelenleg a Gondozási Központ látja el, ahol naponta körülbelül 320 före főznek, illetve a faluba érkező turisták számára is biztosítják az étkezést, amennyiben igény van rá. Emellett ez az intézmény biztosítja a házi segítségnyújtást, valamint az idősek nappali ellátását is.

A közmunka több területen is jelen van: nem csak a földmüvelésben és közétkeztetésben, hanem az iskolakert üzemeltetésében, illetve a vendégházak fenntartásában is segédkeznek a programban részt vevők. Emellett több településhez hasonlóan az illegális hulladéklerakók felszámolását, a belvízelvezető árkok, valamint a külterületi és közutak karbantartását is a közfoglalkoztatás keretében oldják meg. A mezőgazdasági tevékenységhez kapcsolódóan jövöre vonatkozó terveik között szerepel az állattenyésztés beindítása, illetve a fagyasztott áruk mennyiségének növelése, de ehhez a jelenlegi infrastruktúra bővítésére van szükség. Az állattartás hagyományainak felélesztése számos további kérdést is felvet, például képes lehet-e az önkormányzat a közmunkaprogram keretén belül a növénytermesztés mellett az állattartás beindítására is? A növénytermesztés „rovására” hogyan lehetne a munkaerő egy részét átcsoportosítani az állattartásba? Ezen kívül a gyümölcstermesztés feltételeinek kialakítása is további lehetőséget jelenthet, akár a néhány éve müködő tankert révén, a szülők és közmunkások szélesebb körü bevonásával.

\footnotetext{
${ }^{21}$ Az eddig elnyert pályázatok között találunk KEOP, ÉMOP, NKA, LEADER, EACEA forrásból megvalósuló projekteket egyaránt.
} 


\subsection{GAZDÁLKODÁSI LEHETŐSÉGEK, A FÖLD LEGYEN A HELYIEKÉ!}

Véleményünk szerint már nem csak a falu vezetése, hanem a rimóci emberek többsége is felismerte, hogy adottságaikat tekintve a falu gazdaságát leginkább a mezőgazdaságra kellene építeni. Mindenképp pozitívum, hogy a gazdálkodásban a fiatalok közül többen is látnak perspektívát. A felismerés ellenére viszont sajnos nem nagyon mernek, vagy inkább nem nagyon tudnak belevágni a gazdálkodásba. Ennek egyik oka, hogy sok esetben nem rendelkeznek ehhez szükséges tőkével annak ellenére, hogy 1-2 hektárnyi terület müvelésével is érdemes lehet gazdálkodásba kezdeni -, másrészt akadályozó tényezőként említhetjük a gazdálkodási ismeretek hiányát is. További problémát jelent a felvevőpiac hiánya, hiszen a jelenlegi kistermelök is leginkább a környékbeli városok piacain próbálják a portékájukat eladni, ez azonban legfeljebb csak kiegészítö jövedelmet jelent.

A gazdálkodás kapcsán azonban kiemelnénk egy fontos mozzanatot, mely szintén a falu vezetéséhez köthetö. Az utóbbi években olyanok is megkíséreltek Rimóc határában földtulajdonhoz jutni, akiket a helyiek nem ismernek. A polgármester, valamint munkatársai kezdeményezésére azonban több ízben tájékoztatták a lakosságot arról, hogy milyen következményekkel járhat, ha nem a helyiek rendelkeznek a továbbiakban a földterületekröl. Ennek eredményeként a rimóciak többsége úgy döntött, hogy földjét csak helyiek számára fogja értékesíteni, amennyiben a közeljövöben eladja azt.

A birtokrendezés kapcsán felvetődött egy olyan ötlet, miszerint adott földterület adottságaihoz kellene igazítani a termelési struktúrát termények szerint, azonban egyelöre a helyiek kevésbé hajlandók az együttmüködésre. Pedig a sikeres együttmüködés által sokkal hatékonyabbá és eredményesebbé válhatna a gazdálkodás. A birtokok adottságaihoz mért stratégia szerinti gazdálkodás által a termelékenység növekedni tudna. A birtokrendezéshez hozzátartozik, hogy a helyiekben a szövetkezési hajlandóság alacsony, hiszen már maga a szövetkezet kifejezés is rossz emlékeket idéz az emberek többségében. Véleményünk szerint a kellő mértékü, célzott szemléletformáló programok segítségével a lakosság hozzáállása megfelelőképpen megváltoztatható. Ezzel szemben pozitívum, hogy a legtöbb család jelenleg is müveli kertjét, és bizonyos szinten (leginkább a konyhakerti növények tekintetében) törekszik az önellátásra.

\subsection{LAKOSSÁGI SZEMLÉLETFORMÁLÁS}

Rimóci polgármestere elkötelezett híve annak, hogy igazán csak az a rendszer müködhet hosszútávon - akár települési szinten is-, mely a fenntarthatóság elvét nem csak gazdasági, hanem környezeti és társadalmi szinten is szem elött tartja. Ennek kapcsán a szemléletformálást többen is fontos célnak tekintik. Az önkormányzat 2012-ben „Házhoz szállított energia” címmel a Cserfa Egyesülettel együtt szervezett egy megújuló energiaforrásokkal kapcsolatos kiállítást, amely a szemléletformálás mellett a gyakorlati hasznosíthatóságra is felhívta a figyelmet. A kiállításon kívül 2013-ban elindult egy újabb kezdeményezés, a "Vesd bele magad" program. Ezek az akciók sajnos egyelöre kevés rimóciban hagytak mély nyomot. A 
hasonló jellegű kezdeményezéseket szükséges továbbra is támogatni és a rendezvények lehetöségeit megteremteni. Emellett a tankert fenntartása is jó kezdeményezésnek tünik, illetve a kertgazdálkodást érdemes lenne hosszú távon az iskolában az oktatás kötelező részévé tenni.

Az eddigi kezdeményezések során a településnek számtalan nehézséggel kellett szembenéznie. A pozitív törekvéseket hátráltató tényezőket nehéz összefoglalni. A választ több tényezöben kell keresnünk, melyek közül meghatározó a munkaeröpiaci és szociális nehézségek okozta fásultság és motiválatlanság, tőkehiány és együttmüködési nehézségek a lakosság, gazdálkodók és vállalkozók körében. A nehézségeket fokozó tényező a fenti törekvések többnyire hosszú távú megtérülése, amelyet a lakosság közvetlenül nem érez, ezért feltétlenül ki kell egészíteni oktató és ismeretterjesztő tevékenységgel, amely a szemléletváltást is elősegíti a lakosság körében.

A kezdeményezések felkarolójaként és a legnagyobb számú alkalmazottal rendelkezve az önkormányzat szerepe elengedhetetlen ezeknek a programoknak a megszervezésében, lebonyolításában. Az önkormányzat erőforrásai azonban nem elégségesek a feladatok elvégzéséhez. A kötelezettségeken túli feladatellátásához a civil szervezeti szférával és önkéntesekkel szükséges együtt dolgozniuk a célok hosszú távú eléréséhez.

\section{4. ÖSSZEGZÉS}

Ahogy terepi tapasztalataink is mutatják a helyi gazdaságfejlesztéssel kapcsolatos törekvések legkritikusabb tényezője maga a helyi társadalom. A polgármester szerint az önfenntartás tekintetében még mindig nem elég nagy a szükségszerüség, ennek fontosságát egyelőre kevesen ismerték fel, vagyis még most is túlzott jólétről beszélhetünk, annak ellenére, hogy Rimóc több szempontból is hátrányos helyzetünek mondható. Ezt erősíti, hogy sokan saját élethelyzetük javulását rajtuk kívül álló tényezőktől várják. Fontos lenne, hogy a helyi közösség képessé váljon az együttműködésre, felülemelkedve a problémákon, a falu fennmaradásáért tettre készen állva. A rimóci közösség szétaprózódott, a megfelelö lehetőségek és gazdasági adottságok hiánya kezdi ellehetetleníteni a közösségteremtést. A leginkább alulmotivált réteg a roma kisebbség, akiket az alapítvánnyal való szorosabb együttmüködéssel, valamint a szegregálódást kezelő programokkal lehetne újra képessé tenni, hogy a helyi társadalom szerves részévé váljanak.

A falu gazdasági szerkezete kissé ellehetetlenült, hiszen sem a mezőgazdaságban, sem az ipari szférában nincs elegendő munkalehetőség, illetve a kisvállalkozások sincsenek könnyủ helyzetben. Ezt a problémát az önkormányzat lehetőségei szerint orvosolja, ám ez nagyban függ a különböző kormányzati támogatásoktól, valamint a pályázati lehetőségektől. A közmunkaprogram amellett, hogy egy jelentős munkaerőt vonzó ,gazdasági vállalkozásként” müködik, a településen szemléletformáló hatással rendelkezik. Bár a közmunkaprogram esetében rendkívüli nehézséget okoz az anyagi motiváció, de a program vezetői ilyen kereseti lehetőségek mellett is képesek bizonyos szinten ösztönözni a munkaerőt. Továbbá a közmunkaprogram a központosított gazdálkodási struktúra 
megvalósításával törekszik a helyi adottságok kiaknázására, illetve a későbbiekben mintát mutathat a helyi gazdálkodók számára. Továbbá az önkormányzatnak abban is nagy szerepe van, hogy gazdaságfejlesztési tevékenységéhez partnereket keressen, akikkel hosszú távon is fenntartható, önfenntartó tud lenni a település.

Véleményünk szerint a faluban megvalósuló pontszerü fejlesztések egy jól felépített gazdaságfejlesztési program részei, amelyet nagyrészt az önkormányzat koordinál. A falu polgármestere, aki tulajdonképpen a „település motorja”, valamint munkatársai töretlen lelkesedéssel terelik a falut a fenntarthatóság útján. Tisztában vannak helyzetükkel, hogy településük és egyéni sorsuk a tét, ezért az önellátásra törekvés továbbra is kulcsfontosságú feladat marad a falu jövőjét illetően.

\section{IRODALOMJEGYZÉK}

Beluszky P. - Sikos T. T. (2007): Változó falvaink, a magyarországi falvak típusai a harmadik évezred kezdetén. In. Tér és társadalom 2007., 21. évf., 2007/3., pp. 1-29.

Kajner P. - Lányi A. - Takács-Sánta A. (2013): A fenntarthatóság felé való átmenet jó példái Magyarországon. MIS-ÖKO Kft. Budapest. http://elotiszaert.hu/letoltes/nfft/FF_Jo_peldak_MIS-OKO_06_17-v4.7.pdf

Lányi A. (2012): Összegzés: kitörési pontok az ökológiailag fenntartható térségfejlesztés számára. In. Palóc jövő - Vidékfejlesztés alulnézetből (szerk.: Lányi A. - Farkas G.), Érsekvadkert Jövőjéért Alapítvány, Budapest, pp. 45-52.

Németh N. (2012): Helyi gazdaságfejlesztés prezentációs anyag. 2012. május 2. Budapest. http://econ.core.hu/file/download/miskolc2011/Nemeth.pdf

Rapkay B. - Illés S. - Stárics R. (2013): A helyi gazdaságfejlesztés egyes gondolati elözményei és következményei. Földrajzi Közlemények, 137. évf. 1. sz. pp. 28-39.

VÁTI (2010): Területfejlesztési füzetek (2) - Helyi gazdaságfejlesztés. Budapest. http://www.vati.hu/files/articleUploads/21338/TF_fuzet2_Helyi_gazdasagfejlesztes.pdf 